https://oi.org/10.22364/hssl.29.1.06

\title{
ENERGY NEEDS OF THE AGRICULTURAL SECTOR AND THE POTENTIAL FOR ADDRESSING THEM
}

\author{
Inna Honcharuk ${ }^{1}$ \\ Vinnytsia National Agrarian University
}

\begin{abstract}
Agriculture has been considered as one of the priority countries' sectors in our research; the share of agriculture in the GDP of the world leading countries was investigated. The theoretical and practical aspects of the development of non-waste agricultural production are described. The author substantiates the actuality and potential of the introduction of waste-free technology that brings advantages for the enterprises and for the state too.

It is evaluated the assessment of international experience, which is the ability of agricultural waste to produce alternative energy sources. The theoretically available production potential of biogas and bioethanol from biomass of plant and animal origin has been calculated.

The immediate prospect of energy autonomy of agro-industrial production should be based on efficient production and use of biomass. It will help Ukraine to lower dependence on import of energy carriers, will shut down its transformation to raw appendage, will enable to recycle inside a scale resource, having gained thus of hundred thousand of work stations, growth of incomes of citizens and state budget. Production of biofuel at the given stage of development of the state acts as one of the basic accelerants of new global trends in agribusiness industry of Ukraine which will promote its stable development.
\end{abstract}

Keywords: autonomous energy management, agricultural production's waste, biofuels, Ukraine, EU.

\section{Introduction}

Climate change is one of the major problems of global development with potentially serious threats to the global economy and international security as a result of rising risks related to energy security, food and drinking water, the sustainable existence of ecosystems, risks to human health and life.

1 Contact Inna Honcharuk; dnistervnau2017@gmail.com; Vice-Rector for Scientific and Innovative Activities of Vinnytsia National Agrarian University, Sonyachna str. 3, Vinnytsia, Ukraine, 21008. 
Climate change has become one of the thorniest issues of the world economy and policy in the context of developing strategies for reducing greenhouse gas emissions and the gradual transition to low carbon development of all sectors of the economy and components of human life.

Renewable energy sources, combined with energy efficiency improvements, are the most powerful tool in decarbonising national and global economies.

The use of renewable energy has many potential benefits, including reducing greenhouse gas emissions, diversifying energy supplies, and decreasing the dependence on fossil fuel markets (particularly, oil and gas). The growth of renewable energy sources can also stimulate employment in the EU by creating jobs in new "green" technologies and ensuring energy autonomy in the agricultural sector through the use of agricultural waste for biofuels.

\section{Literature Review}

Nowadays, a number of studies of Ukrainian and foreign scientists are devoted to these issues, and a wide range of issues related to the influence of the use of the crop and livestock industry' waste for improving the AgroIndustrial Complex's efficiency and replenishing the energy balance of the country have been considered.

Among the scientists who have paid considerable attention to research on this subject, one can mention Angheluta, S. P., Burlacu, S., Diaconu, A., \& Curea, C. S. (2019), Fei Li, Shengkui Cheng, Huilu Yu, Dewei Yang (2016), Honcharuk, I. V., Tomashuk, I. V. (2017)., Kaletnik, G. M., Goncharuk, T. V. (2013), Kaletnik, G. (2018)., Lybæk, R., Christensen, T. B., \& Kjær, T. (2013), Trypolska, H. S., Diachuk, O. A., Podolets, R. Z., Chepeliev, M. H. (2016) and others.

There are several reasons for the current economic and social need for biofuel production and consumption in Ukraine, according to Kaletnik, G. (2018), starting from energy security considerations, diversifying national production, supporting innovation and ending with the economic and social efficiency of biofuel market development on the basis of high motivation for agrarian sector growth, positive social shift in rural employment growth and environmental security thanks to renewable energy sources.

As it has been noted by Angheluta, S. P., Burlacu, S., Diaconu, A., \& Curea, C. S. (2019), sustainable development can be achieved through the use of technologies which conserve the environment. One of these technologies is the production of energy from renewable energy sources, reduces the use of fossil fuels and affects the process of reducing greenhouse gas emissions into the atmosphere. 
The global livestock industry is growing, generating a large amount of waste. having reviewed waste from different viewpoints, Fei Li, Shengkui Cheng, Huilu Yu, Dewei Yang (2016), indicate that waste can be either important anaerobic fermentation materials for biogas production, or if they enter the environment without proper processing, be serious sources of soil and water systems contamination. Considering that in developing countries, the need for energy is a major threat to sustainable development and livelihoods, the production of renewable energy is essential.

Taking into account the modern theoretical research viewpoints, ideas and recommendations of these scientists, we should note that this topic is the subject to study and needs further scientific research.

\section{Material and methods}

Monographic, calculation, mathematical and statistical.

The calculation method is widely used in forecasting and planning the production and economic processes of development of the livestock industry. It involves developing several options for solving particular economic problems, evaluating them, and then choosing the best one. This method involves many techniques which ensure the relative accuracy of economic forecasts and targets for energy balance calculations.

The monographic method is used for a comprehensive and in-depth study of single phenomena, processes and the identification of causal relationships of their development. It is indispensable in the detailed study of individual observations of livestock waste.

The mathematical and statistical method uses rational methods of systematisation, processing and analysis of statistical observations data of mass phenomena in order to establish characteristic statistical patterns, use for scientific and practical conclusions and is based on the probabilistic nature of these phenomena.

\section{Results of research}

According to Eurostat, the share of renewable energy sources in the total energy balance of the EU member states has almost doubled since 2004 to 2018. In 2018, almost half (54.6\%) of energy in gross final energy consumption in Sweden was generated from renewable sources, Finland - 41.2\%, Latvia - 40.3\%, Denmark - 36.1\% and Austria - 33.4\%. The EU member states with the lowest share of renewable energy in the energy balance are the Netherlands (7.4\%), Malta (8.0\%), Luxembourg $(9.1 \%)$ and Belgium $(9.4 \%)$. By 2020 , the EU has aimed to reach $20 \%$ of gross 
final consumption of energy from renewable sources, and some countries have already crossed that line.

This positive development of alternative energy in the EU member states was driven by legally binding targets for increasing the share of renewable energy adopted by Directive 2009/28/EU on the promotion of the use of energy from renewable sources and the adoption of The Climate Change Plans to reduce carbon dioxide emissions.

According to the State Statistics Service of Ukraine, the share of energy supply from renewable sources in Ukraine in 2018 is only $4.6 \%$ (including hydropower $-1 \%$, biofuels and waste $-3.4 \%$, wind and solar $-0.2 \%$ ), and according to the Energy Strategy 2035, it should reach 8\% in 2020 (Figure 1). (Eurostat, State Statistics Service of Ukraine, 2018).

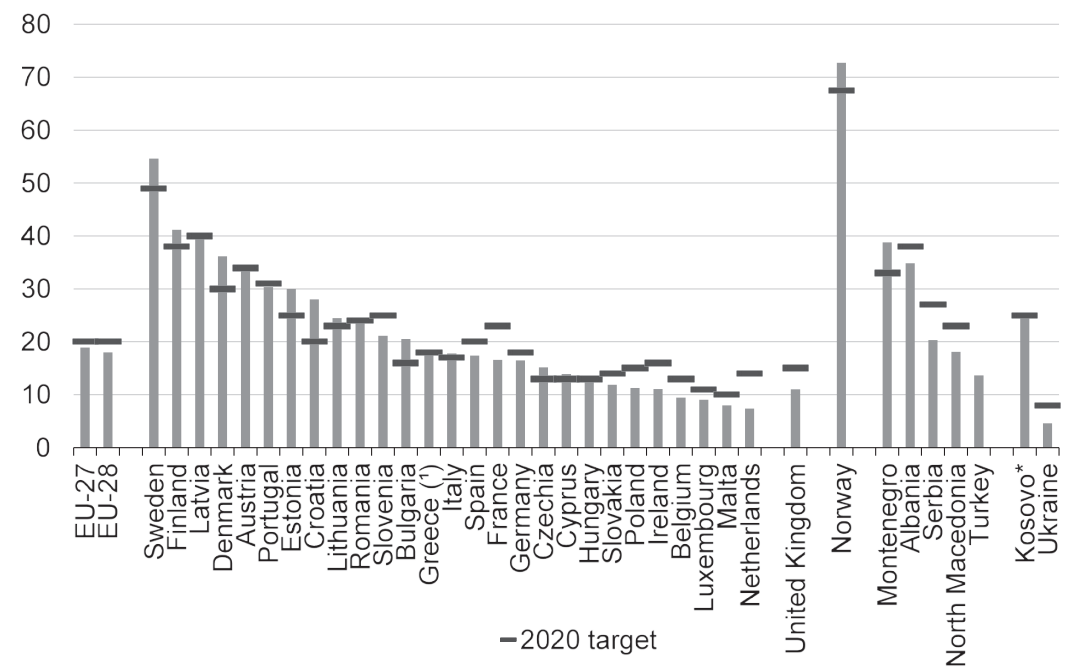

Figure 1. Share of energy from renewable sources, 2018

(\% of gross final energy consumption)

* This designation is without prejudice to positions on status, and is in line with UNSCR 1244/1999 and the ICJ Opinion on the Kosovo declaration of independence.

Source: Eurostat, State Statistics Service of Ukraine

Ukraine has considerable natural potential to make a "green" transition in all sectors of the economy, which remains untapped.

Agriculture occupies a small share in the final energy consumption structure (in 2018, as a whole, in the EU member states it was 2.68\%, in Ukraine - 1.695\%) (Figure 2) (Eurostat, State Statistics Service of Ukraine, 2018). However, this sector has sufficient potential to improve energy 
efficiency and transition to renewable energy sources and to assist other sectors of the economy through:

- increasing energy and resource efficiency of agricultural products and foodstuffs production;

- reducing the consumption of carbon intensive energy sources and maximising the use of renewable energy sources for switching the agro-industrial sector to full self-sufficiency in energy resources;

- rising the sustainable production of biomass, biofuels and other renewable energy sources to support the implementation of the "green" transition in other sectors of the economy.
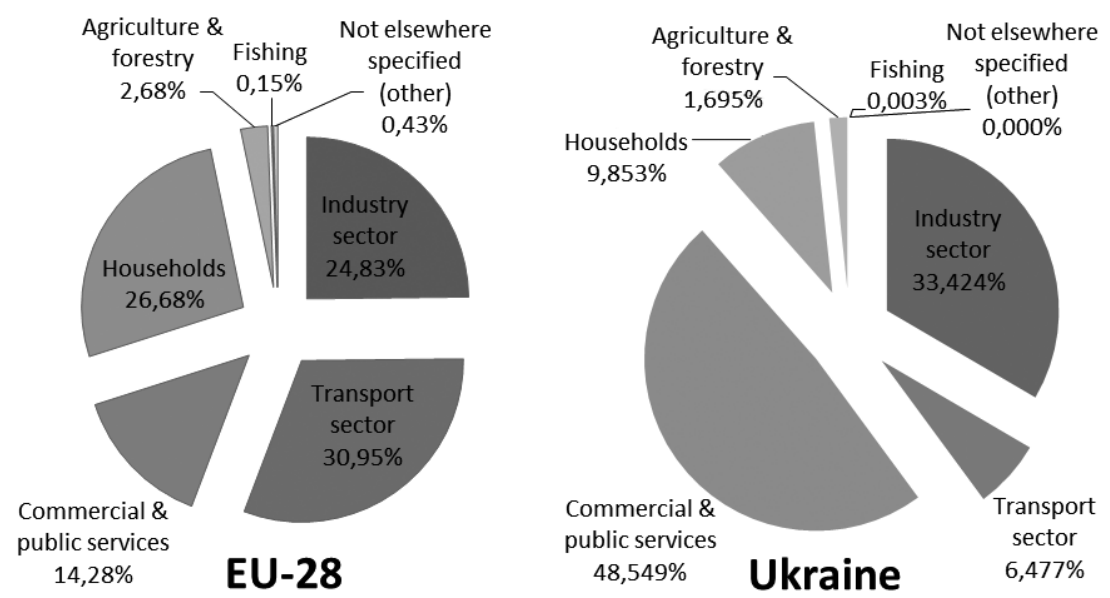

Figure 2. Share of final energy consumption by economic sectors, 2018 (\% of gross final energy consumption) Source: Eurostat, State Statistics Service of Ukraine

The EU agriculture and forestry play a significant role in the renewable energy supply. Renewable energy production from agriculture and forestry in the EU-27 reached 98.4 million tonnes of oil equivalent in 2010, accounting for $11.9 \%$ of total primary energy production and $59 \%$ of total renewable energy production. $60 \%$ of renewable energy from primary biomass sources in agriculture consists of biofuels (48\% from biodiesel energy crops and $12.2 \%$ from ethanol energy crops) and (39.8\% from agricultural biogas).

The contribution of agriculture to total primary energy production and to total renewable energy production increased by 1.8 percentage points between 2004 and 2010 (from $0.3 \%$ to $2.1 \%$ ) and by 8.4 percentage points (from $2.2 \%$ to $10.6 \%$ ), respectively. 
According to assessments of Directorate-General for Agriculture and Rural Development, in 2011, 6.1 million hectares of agricultural land in the EU-27, equivalent to $3.4 \%$ of the total agricultural land, was directly targeted at biomass production and energy production. The total area under cultivation of biomass and energy crops continues to increase in the EU-27.

Especially, in the agricultural sector, renewable energy production is very unevenly distributed across countries, with Germany (51\%) and France (13\%) producing $64 \%$ of all renewable energy in the EU-27 agricultural sector in 2010. The share of the agricultural sector in the production of total renewable energy, however, is the highest in Belgium (30.8\%). It is the lowest in Estonia $(0.3 \%)$. In the forest sector, differences between member states in the renewable energy production are less express. Germany (15.1\%), France (13\%), Sweden (12.3\%), Finland (9.5\%) and Poland (7.3\%) contributed $57 \%$ to the total EU renewable energy production in the EU-27 in 2010. The absolute contribution of forestry to total energy production is particularly high in Estonia (97\%), Latvia (81.9\%), Lithuania (76.5\%), Portugal (46.3\%), Finland (44.6\%), Luxembourg (40\%), Austria (35.7\%) and Sweden (30\%), while below the EU-27 average is in the United Kingdom (1\%) and the Netherlands (1.5\%).

According to the United Nations Economic Commission for Europe (UNECE), on average the share of agriculture in the GDP of the EU member states is 2 to $5 \%$, while in Ukraine, agriculture accounts for more than $12 \%$ of GDP and the dynamics of statistical data, shows that the AIC is gradually reaching the top (United Nations Economic Commission for Europe, 2019).

In 2018, according to the Food and Agriculture Organization, the gross harvest of basic crops accounts for more than $50 \%$ of the gross corn harvest by EU Member States, more than $43 \%$ for potatoes, and about $18 \%$ for wheat. Ukraine also has significant potential for livestock production. Despite the decline in livestock, the Ukrainian agricultural sector in 2018 holds more than 3530 thousand head of cattle, 6109 thousand head of pigs, 1309 thousand head of sheep and goats, a slight growth demonstrates poultry (over 203 million birds) (Table 1) (The Food and Agriculture Organization, 2018).

While conducting agricultural production, a large number of byproducts and agricultural wastes are formed which can be used to produce biofuels. These include all forms of plant material that can be used to produce energy: wood, grass and crops, forestry and livestock waste, as well as household and industrial waste not always of plant origin, but characterised by the same principles of their utilisation. 
Table 1. Key indicators of agro-industrial complex of Ukraine and EU in 2018

\begin{tabular}{|l|c|c|c|c|}
\hline Agricultural crops & Unit of measurement & Ukraine & \% to the EU & $\begin{array}{c}\text { the European } \\
\text { Union }\end{array}$ \\
\hline Gross harvest of basic agricultural crops: & \multicolumn{5}{|l|}{} \\
\hline wheat & thousand tons & 24652.84 & 17.86 & 138049.23 \\
\hline maize & thousand tons & 35801.05 & 51.73 & 69207.04 \\
\hline barley & thousand tons & 7349.14 & 13.02 & 56465.51 \\
\hline rye & thousand tons & 393.78 & 6.29 & 6263.53 \\
\hline sugar beet & thousand tons & 13967.70 & 11.68 & 119579.91 \\
\hline potatoes & thousand tons & 22503.97 & 43.07 & 52253.11 \\
\hline sorghum & thousand tons & 193.98 & 23.56 & 823.42 \\
\hline Livestock of farm animals: & thousand heads & 3530.800 & 3.99 & 88453.217 \\
\hline cattle & thousand heads & 6109.00 & 4.06 & 150321.266 \\
\hline pigs & thousand heads & 1309.300 & 1.18 & 111191.796 \\
\hline Sheep and Goats &
\end{tabular}

Source: The table created by the author according to the data of The Food and Agriculture Organization (FAO)

It should be noted that there is no unanimity among domestic and foreign scientists regarding the definition of "waste". In an economic encyclopaedia, waste is defined as a part of production that has been generated in the process of production, use or processing of agricultural raw materials and in long-term storage damages the environment.

"All objects of entrepreneurial activity are consumers of natural resources and conditions, producing in addition to the really necessary products and services, specific products - wastes", - I. H. Hrechanovska writes. "Wastes are an inevitable consequence of production, which are included in the cost of goods and themselves become a commodity, that is, a specific product of production, as they are involved in the structure of the system of production, consumption, accumulation", - said S. H. Shuntova.

From the viewpoint of V. I. Kerzhakov and O. M. Derykolenko, with the development of scientific and technological progress, the number of substances called "waste" will decrease, as technologies emerge, the raw material for which wastes generated earlier. In this case, it is secondary material resources. A similar position has been expressed by O. A. Novikov and H. A. Makhovykov, emphasising that waste is secondary material resources or secondary raw materials, and which, as a result of the process of restoration of consumer value, are transformed into a new object of 
work capable of addressing the needs of the new production process as much as possible.

It is necessary to agree with N. Korniakova that the concept of "waste" is multi-specific and can be considered on the basis of different approaches. In particular, given their physical properties, waste can be defined as any, mainly solids, substances, materials, or objects created in the course of human activity. In terms of economic characteristics, waste is a resource for other types of production. With regard to environmental properties, waste is considered to be a factor in the negative impact on the environment in the process of their formation, use or management. Depending on the quantitative and qualitative quantities of waste and their composition, such an impact can be defined as dangerous (Andreichenko, A. V., 2017).

Different definitions of waste category are contained in the regulations of Ukraine. In the Law of Ukraine "On Waste" (1998), waste means any substances, materials and objects that have been generated in the process of production or consumption, as well as goods (products) that have completely or partially lost their consumer properties and do not have subsequent use at the place of their formation or discovery and from which their owner disposes, intends or should be disposed of by disposal or disposal.

Considering the classification of wastes in agriculture, the author emphasises that the agro-industrial complex is an inter-sectoral complex that combines agriculture, industries providing agriculture with means of production, and industries for processing agricultural products.

A significant part of agricultural waste (more than $80 \%$ ) is made up of agricultural waste, plant and animal husbandry. By-products of agricultural production according to the "Waste Classifier" (DK 005-1996) (group 01) include:

- wastes from cereals production, vegetables and horticultural products;

- wastes from animal husbandry and livestock production;

- wastes from the production of mixed farm products;

- waste from rendering services in plant and animal husbandry;

- services specialised in the management of waste of agricultural production provided at the place of generation of waste.

The National Waste Management Strategy in Ukraine until 2030 states that traditionally agricultural waste in Ukraine is divided into animal husbandry, crop waste and agrochemical waste.

The agricultural production wastes involve: organic crop wastes; organic livestock and poultry waste; bio-waste (animal and poultry carcasses); residual amounts of fertilisers, chemicals and biologicals for plant protection, veterinary preparations. 
According to the Law of Ukraine "On State Support for Agriculture of Ukraine" (paragraph 2.15) of 2004, waste from the production of agricultural products (goods) also relates to agricultural products (goods).

This list includes:

- organic fertilisers and mixtures of organic and mineral fertilisers (if the proportion of organic fertilisers is more than $50 \%$ of the total weight of such mixtures);

- all biofuels and energy obtained from the processing of agricultural products (goods) and their wastes (biogas, biodiesel, ethanol, solid biofuels - if their production uses more than $50 \%$ of agricultural production (its wastes) of the total amount of electricity used, steam hot water, etc.).

Considering Ukraine's commitment to adopt EU technical standards and rules in a 10-year transition period, with regard to agro-industry, it is necessary to consider the classification of agricultural waste in the EU.

It is worth noting that the EU does not have separate legislation on agricultural waste. European Waste Catalogue has been developed for all EU Member States, in which agricultural waste is included in Chapter 2, Chapter 0201:

- 02 Waste from agriculture, horticulture, hunting, fishing and aquaculture primary production, preparation and processing;

- 0201 Primary production wastes;

- 020101 Sludge after washing and cleaning;

- 020102 Animal tissue waste;

- 020103 Waste from plant tissues;

- 020104 Plastic waste (except packaging);

- 020105 Waste of agrochemistry;

- 020106 Animal faeces, urine and pus (including spoiled straw);

- 020107 Waste from forest use;

- 020199 Other wastes.

Ukraine's legislation governing agricultural waste is expected to be brought into line with EU legislation by 2025.

From the author's point of view, it is advisable to classify agrarian and industrial complex waste according to the characteristics shown in Table 2 .

Today, agricultural waste, although a valuable raw material, is not always used. Agricultural enterprises do not plan indicators which would characterise their work on processing them into biofuels, increasing soil fertility, fertilising, especially organic. Therefore, there is a need for sound waste management.

Despite the range of environmental policies and programming adopted in Ukraine, waste management has not been properly reflected, despite the fact that waste can cause significant damage to public health and the environment. 
Table 2. Classification of agricultural wastes

\begin{tabular}{|c|c|}
\hline $\begin{array}{l}\text { According to sources } \\
\text { of origin }\end{array}$ & $\begin{array}{l}\text { - wastes from main industries; } \\
\text { - wastes from auxiliary industries; } \\
\text { - wastes from subsidiary industries }\end{array}$ \\
\hline $\begin{array}{l}\text { According to sources } \\
\text { of formation }\end{array}$ & $\begin{array}{l}\text { - plant: not the grain fraction of the crop (straw, stems), waste } \\
\text { of grain and seeds; buds of leaves of root tubers; } \\
\text { - animal: excrement of animals, waste of slaughterhouses; } \\
\text { - chemical }\end{array}$ \\
\hline $\begin{array}{l}\text { According to } \\
\text { the aggregate } \\
\text { condition }\end{array}$ & $\begin{array}{l}\text { - } \text { solid; } \\
\text { - rare; } \\
\text { - pasty; } \\
\text { - gaseous } \\
\end{array}$ \\
\hline $\begin{array}{l}\text { According to material } \\
\text { intensity }\end{array}$ & $\begin{array}{l}\text { - large tonnage; } \\
\text { - light tonnage }\end{array}$ \\
\hline $\begin{array}{l}\text { According to } \\
\text { the degree of } \\
\text { environmental impact }\end{array}$ & $\begin{array}{l}\text { - safe; } \\
\text { - dangerous (contain harmful substances having dangerous } \\
\text { properties) }\end{array}$ \\
\hline $\begin{array}{l}\text { According to } \\
\text { the method of disposal }\end{array}$ & $\begin{array}{l}\text { - on one's own; } \\
\text { - with the help of processing enterprises }\end{array}$ \\
\hline $\begin{array}{l}\text { According to } \\
\text { the further use }\end{array}$ & $\begin{array}{l}\text { - as fertilisers - secondary raw materials of agricultural } \\
\text { production that are used or can be used for the production } \\
\text { of organic fertilisers and restoration of soil fertility (manure } \\
\text { and animal manure, non-commercial part of the crop yield, } \\
\text { etc.); } \\
\text { - for food production through industrial processing; } \\
\text { - as forage; } \\
\text { - as fuel - biomass that is specially grown for energy needs (oil } \\
\text { and sugar-containing crops, algae, energy crops, etc.). }\end{array}$ \\
\hline $\begin{array}{l}\text { According to } \\
\text { processing methods }\end{array}$ & $\begin{array}{l}\text { - biological method; } \\
\text { - thermal method; } \\
\text { - mechanical method; } \\
\text { - chemical method }\end{array}$ \\
\hline
\end{tabular}

Source: The table created by the author according to the data of Andreichenko, (2017), Zamula, I. V., Bondarchuk V. V. (2013), Zarichanska, Ye. V. (2008).

Vegetable and animal wastes, mixed food waste; animal excrement, urine, pus occupy the main share in conducting economic activities of agricultural enterprises.

Waste utilisation is the predominant type of animal excrement, with this method eliminating twice as much waste as with the production of animal waste / mixed foods. Incineration is the most common way of dealing with vegetable waste, i.e. 418.7 thousand tons was burned for energy in 2018. The disposal of the three main types of agricultural waste is currently under-practiced in Ukraine (Table 3). 
Table 3. Generation and management of I-IV waste classes by categories of materials in agriculture of Ukraine in 2018 , thousand tons

\begin{tabular}{|l|c|c|c|c|}
\hline \multicolumn{1}{|c|}{ Indicator } & Created & Recycled & Burnt & $\begin{array}{c}\text { Removed to specially } \\
\text { designated places or objects }\end{array}$ \\
\hline $\begin{array}{l}\text { Animal waste and mixed } \\
\text { food waste }\end{array}$ & 607.5 & 295.3 & 9.4 & 1.7 \\
\hline Waste of plant origin & 7829.3 & 2638.2 & 418.7 & 154.0 \\
\hline $\begin{array}{l}\text { Animal excrement, urine } \\
\text { and pus }\end{array}$ & 3233.8 & 2300.6 & - & 72.0 \\
\hline
\end{tabular}

Source: table created by the author according to the State Statistics Service of Ukraine

Waste can be processed by biological, thermal, mechanical or chemical methods, depending on their characteristics and properties. For this purpose, it is advisable for the enterprise to conduct waste analysis by the methods of their processing, as well as on the grounds that it will occur at the expense of own or involved forces.

Biomass and agricultural waste used for energy purposes must be produced in accordance with sustainable development criteria. Such criteria include the prevention of negative environmental impacts, the promotion of the economic development of the region, the conservation of biological diversity, and the like.

Processing of by-products of crop and livestock products on biofuels would reduce the use of purchased energy resources, whose prices are constantly rising.

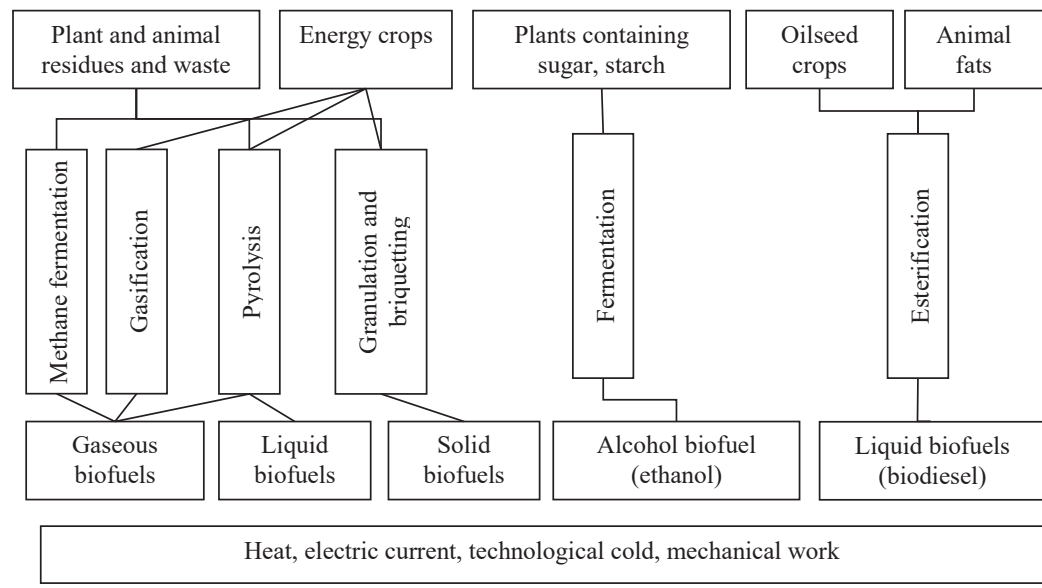

Figure 3. Scheme of the use of agricultural biomass for energy needs Source: The figure created by the author according to the Kaletnik, G. M., Goncharuk, T. V. (2013) 
According to the Law of Ukraine "On Alternative Fuels" №1391-XIV of 14.01.2000 biological fuels (biofuels) - solid, liquid and gaseous fuels made from biodegradable raw materials (biomass), which can be used as fuel or a component of other types fuel. Biofuels in Ukraine are classified as follows: liquid (ethanol, methanol, biodiesel), solid (wood, briquettes, fuel pellets, wood chips, straw, husks) and gaseous (biogas, hydrogen).

A block diagram of the use of agricultural biomass for energy needs is presented in Figure 3.

The utilisation of biomass and agricultural waste potential is one of the factors for the sustainable development of society, as well as the food, energy and environmental security of the state.

It is estimated that the biomass and waste production potential of the EU member states in 2020 may amount to 41048 million tons in agriculture, 74770 million tons of forestry, and 16901 million tons of waste. (Table 4).

Table 4. Assessment of biomass supply and waste from different sectors (million tons, \%), 2006-2020, EU-27

\begin{tabular}{|l|c|c|c|c|}
\hline \multirow{2}{*}{} & \multicolumn{4}{|c|}{ Biomass supply } \\
\cline { 2 - 5 } & \multicolumn{2}{|c|}{2015} & \multicolumn{2}{c|}{2020} \\
\cline { 2 - 5 } & Mtoe & $\%$ & Mtoe & $\%$ \\
\hline Agriculture & 28359 & 26.2 & 41048 & 30.9 \\
\hline Forestry & 67454 & 62.2 & 74770 & 56.4 \\
\hline Waste & 12627 & 11.6 & 16901 & 12.7 \\
\hline Total & 108440 & 100.0 & 132720 & 100.0 \\
\hline
\end{tabular}

Source: DG Agriculture and Rural Development / DG Energy - National Renewable Energy Action plans (NREAPs)

According to scientists' assessments, the total biomass potential available for bioenergy in Ukraine is 89950 thousand tons, and the used ones are 10466 thousand tons, or $11.6 \%$.

There are already several hundred enterprises operating in Ukraine for the production of pellets, briquettes, thousands of small, medium and large boilers for wood waste, firewood, chips, granules, more than 200 boilers and generators on bale straw, sunflower husk, corn stalks and others. raw materials. Plantations of energy willow (nearly 5 thousand hectares), miscanthus (about 2 thousand hectares) are cultivated (Roik, M. V, Ganzhenko, O. M., Tymoshchuk, V. L., 2014).

Biogas production potential is 20 billion $\mathrm{m}^{3}$ per year due to the use of livestock and biomass waste from bioenergy crop residues (Tables 6 and 7).

It should be noted that in the last 3-4 years in Ukraine in the field of bioenergy began to recover. A number of bioenergy, first of all, biogas 
projects of the European level have been implemented, in particular, in the companies - "Astarta", "Goodwelli Ukraine", "Ekoprod", "Rokytne", "Slavuta", "Nyva", "Dniprovska", "Hnidavskyi Sugar Factory" and others. The large agricultural enterprise "Myronivskyi Khliboproduct" is building a powerful $20 \mathrm{MW}$ biogas complex near Ladyzhyn of Vinnytsia region.

Table 6. Potential for biogas production from livestock wastes in Ukraine in 2018

\begin{tabular}{|c|c|c|c|c|c|c|c|c|}
\hline \multirow[t]{2}{*}{ Indicator } & \multirow{2}{*}{$\begin{array}{l}\text { Livestock, } \\
\text { million } \\
\text { animals }\end{array}$} & \multirow{2}{*}{$\begin{array}{c}\text { Manure } \\
\text { or litter } \\
\text { output, } \\
\text { m³ }^{3} / \\
\text { animal / } \\
\text { place / } \\
\text { year }\end{array}$} & \multicolumn{2}{|c|}{$\begin{array}{l}\text { Biogas output, } \mathrm{Nm}^{3} \text { / } \\
\text { t of substrate }\end{array}$} & \multirow{2}{*}{$\begin{array}{c}\text { Methane } \\
\text { content, } \\
\%\end{array}$} & \multicolumn{2}{|c|}{$\begin{array}{c}\text { Biogas } \\
\text { output, } \\
\mathrm{Nm}^{3} / \\
\text { year }\end{array}$} & \multirow{2}{*}{$\begin{array}{c}\begin{array}{c}\text { Bio- } \\
\text { methane } \\
\text { output, } \\
\mathrm{Nm}^{3} \text { / } \\
\text { year }\end{array} \\
\text { min }\end{array}$} \\
\hline & & & $\begin{array}{l}\text { Meas- } \\
\text { urement } \\
\text { range* }^{*}\end{array}$ & Average & & $\min$ & $\max$ & \\
\hline Cattle & 3.5 & $7.5-21.0$ & $20-30$ & 25 & 60 & 525 & 2205 & 315 \\
\hline Pigs & 6.2 & $1.2-6.0$ & $20-35$ & 28 & 65 & 148.8 & 1302 & 96.7 \\
\hline Poultry & 204.8 & $\begin{array}{c}7.5(\mathrm{x} 100 \\
\text { animal } \\
\text { place per } \\
\text { year) }\end{array}$ & $130-270$ & 140 & 64 & 1997 & 4147 & 1278.1 \\
\hline
\end{tabular}

Source: the table is formed by the author according to the data of the State Statistics Service and own calculations and own calculations

For biogas, corn silage, sugar beet pulp, animal manure, poultry manure, etc. are used. Without violating food security, the domestic agroindustrial complex can use part of the acreage for biomass production for biofuel production. The potential for biogas and bioethanol production from energy crops was calculated based on the acreage utilisation for their crops in 2018.

Table 7. Potential output of biogas and biomethane from bioenergetic plants in Ukraine in 2018

\begin{tabular}{|l|c|c|c|c|c|c|}
\hline $\begin{array}{c}\text { Agricultural } \\
\text { crops }\end{array}$ & $\begin{array}{c}\text { Potential } \\
\text { of sown } \\
\text { area, } \\
\text { million ha }\end{array}$ & $\begin{array}{c}\text { Yield } \\
\text { capacity, } \\
\mathbf{t} / \mathbf{h a}\end{array}$ & $\begin{array}{c}\text { Biogas } \\
\text { output, } \\
\mathbf{m}^{\mathbf{3}} / \mathbf{t}\end{array}$ & $\begin{array}{c}\text { Biomethane } \\
\text { output, } \\
\mathbf{m}^{3} / \mathbf{t}\end{array}$ & $\begin{array}{c}\text { Biogas } \\
\text { output, } \\
\text { billion } \\
\mathbf{m}^{3} / \text { year }\end{array}$ & $\begin{array}{c}\text { Bio-methane } \\
\text { output, } \\
\text { billion } \\
\mathbf{m}^{\mathbf{3}} / \text { year }\end{array}$ \\
\hline Corn for silage & 4.5 & 80 & 16.0 & 8.5 & 72 & 38.25 \\
\hline Sugar beets & 0.2 & 50.8 & 10.9 & 6.0 & 2.18 & 1.2 \\
\hline Sugar Sorghum & 0.04 & 4.6 & 17.6 & 8.8 & 0.7 & 0.35 \\
\hline Total & 4.74 & & & & 44.88 & 39.8 \\
\hline
\end{tabular}

Source: the table is formed by the author according to the data of the State Statistics Service and own calculations 
A number of sugar mills produce molasses bioethanol and pulp biogas, as well as organic solvents, feed additives, organic bard fertilisers, microbiological preparations and other products. (Marchenko, V. M., Kit, A. V., 2018).

Table 8. Ethanol production potential of different raw materials in Ukraine in 2018

\begin{tabular}{|l|c|c|c|c|c|}
\hline $\begin{array}{c}\text { Crop (raw } \\
\text { material) }\end{array}$ & $\begin{array}{c}\text { Sown areas, } \\
\text { thousand } \\
\text { hectares }\end{array}$ & $\begin{array}{c}\text { Yield, } \\
\text { centner } / \mathbf{k g}\end{array}$ & $\begin{array}{c}\text { Output of } \\
\text { ethanol from } \\
\mathbf{1} \text { ton of raw } \\
\text { material, } \mathbf{~}\end{array}$ & $\begin{array}{c}\text { Ethanol yield } \\
\text { per } \mathbf{1} \text { ha, } \mathbf{~} / \text { ha }\end{array}$ & $\begin{array}{c}\text { Ethanol } \\
\text { production } \\
\text { potential per } \\
\text { year, ppm }\end{array}$ \\
\hline sugar beets & 276 & 508.5 & 100 & 5085 & 1.2 \\
\hline corn (grain) & 4579.7 & 78.4 & 416 & 3261 & 12.8 \\
\hline wheat & 6614.0 & 37.3 & 395 & 1473 & 8.3 \\
\hline barley & 2492.2 & 29.6 & 370 & 1095 & 2.3 \\
\hline potato & 1319 & 324 & 114 & 3694 & 4.1 \\
\hline rye & 148.7 & 26.6 & 340 & 904 & 0.1 \\
\hline
\end{tabular}

Source: the table is formed by the author according to the data of the State Statistics Service and own calculations

Nowadays the renewable energy market is developing rapidly and is an element of modern, waste-free manufacturing in the industry as a whole, and of the agro-industrial complex in particular. For businesses that have agricultural or food waste, it is possible to reduce the amount of costs in the article "Fuel and electricity for technological purposes", which can significantly reduce the cost of all products manufactured at the enterprise. (Kulakovska, T. A., Shekera, S. S., 2012).

In 2018, Ukrainian agricultural enterprises purchased oil products and energy materials in the amount of 109.3 thousand tons gasoline, 1,445 thousand tons diesel fuel, 4,2 thousand tons fuel oil, 261.9 thousand tons oils and oils, 57.6 thousand tons coal, 298.9 million $\mathrm{m} 3$ of natural gas. In spite of the fact that the volume of purchased fuel and lubricants by agricultural enterprises by years differs in volume by a small amount, however, the total cost of purchased fuel and lubricants and other energy resources increases significantly annually.

This is due to the fact that despite periodic significant drops in oil prices, sometimes even 1.5-2 times, oil traders not only do not proportionally reduce the price, keep it high and even increase it (Figure 4).

According to the State Statistics Service of Ukraine, the price of gasoline in 2018 has almost doubled (in 2018 by UAH 9548,3 / t, compared to 2015); a similar trend is observed for diesel fuel (increased in 2018 compared to 2015 by $88892,9 \mathrm{UAH} / \mathrm{t}$ ), natural gas (price increased by $2596,3 \mathrm{UAH} /$ thousand $\mathrm{m} 3$ ) and other types of energy resources (Table 9). 


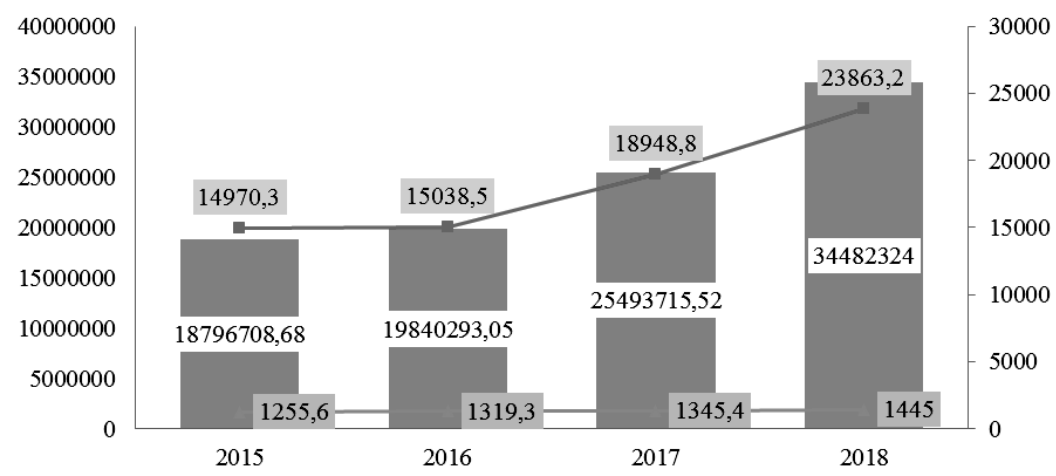

Costs for the purchase, thousand UAH $\rightarrow$-Price, $\mathrm{UAH} / \mathrm{t}$

- Volume of the purchase, thousand tons

Figure 4. Costs for the purchase of diesel fuel in Ukraine Source: State Statistics Service of Ukraine

Table 9. Purchase of petroleum products and energy materials by the agricultural enterprises of Ukraine for 2015-2018

\begin{tabular}{|c|c|c|c|c|c|c|}
\hline Indicator & $\begin{array}{c}\text { Unit of } \\
\text { measurement }\end{array}$ & 2015 & 2016 & 2017 & 2018 & $\begin{array}{c}\text { Deviation, } \\
+/-\end{array}$ \\
\hline \multicolumn{7}{|c|}{ Volume } \\
\hline Gasoline & thousand tons & 132.8 & 130.3 & 125.3 & 109.3 & -23.5 \\
\hline Diesel & thousand tons & 1255.6 & 1319.3 & 1345.4 & 1445.0 & 189.4 \\
\hline Fuel oil & thousand tons & 1.8 & 2.0 & 2.9 & 4.2 & 2.4 \\
\hline Oils & thousand centres & 221.7 & 240.5 & 233.9 & 261.9 & 40.2 \\
\hline Coal & thousand tons & 60.6 & 65.0 & 74.5 & 57.6 & -3 \\
\hline Natural gas & million $\mathrm{m}^{3}$ & 285.0 & 338.4 & 330.1 & 298.9 & 13.9 \\
\hline \multicolumn{7}{|c|}{ Price } \\
\hline Gasoline & hrn/t & 17575.5 & 18601.9 & 22750.0 & 27123.8 & 9548.3 \\
\hline Diesel & hrn/t & 14970.3 & 15038.5 & 18948.8 & 23863.2 & 8892.9 \\
\hline Fuel oil & hrn/t & 9310.8 & 10633.0 & 13347.4 & 15962.8 & 6652 \\
\hline Oils & hrn/c & 3468.2 & 3543.1 & 3984.3 & 3991.5 & 523.3 \\
\hline Coal & hrn/t & 1424.5 & 1870.4 & 2526.2 & 3088.7 & 1664.2 \\
\hline Natural gas & hrn/t rpH/th. $\mathrm{m}^{3}$ & 6764.7 & 6670.2 & 7496.1 & 9361.0 & 2596.3 \\
\hline
\end{tabular}

Source: table created by the author according to the State Statistics Service of Ukraine

In the structure of direct costs for the production of agricultural products of all types of the agrarian sector's economic entities, the purchase of petroleum products and energy materials is $10,8 \%$ in the cost structure; 
for small farms, the purchase of fuel and lubricants is even more $-14,9 \%$ (Table 10).

Table 10.Cost structure of agricultural production (services) in all enterprises in $2018^{1}$

\begin{tabular}{|c|c|c|c|c|}
\hline \multirow[b]{2}{*}{ Types of costs } & \multicolumn{2}{|c|}{ All enterprises ${ }^{2}$} & \multicolumn{2}{|c|}{ Including private farms } \\
\hline & $\begin{array}{l}\text { Million } \\
\text { UAN }\end{array}$ & $\begin{array}{c}\% \text { to } \\
\text { the total } \\
\text { costs }\end{array}$ & $\begin{array}{c}\text { Million } \\
\text { UAN }\end{array}$ & $\begin{array}{l}\% \text { to } \\
\text { the total } \\
\text { costs }\end{array}$ \\
\hline Costs - total & 442993.4 & 100.0 & 68397.4 & 100.0 \\
\hline Direct costs - total & 247997.2 & 56.0 & 41524.8 & 60.7 \\
\hline \multicolumn{5}{|l|}{ including } \\
\hline seeds and planting materials & 35963.5 & 8.1 & 7585.1 & 11.1 \\
\hline fodder & 52036.9 & 11.7 & 2434.2 & 3.6 \\
\hline including purchased fodder & 22866.8 & 5.2 & 1195.8 & 1.7 \\
\hline other agricultural products & 6496.8 & 1.5 & 330.9 & 0.5 \\
\hline inorganic fertilisers & 57695.7 & 13.0 & 13150.0 & 19.2 \\
\hline oil products & 39035.6 & 8.8 & 9362.3 & 13.7 \\
\hline electric power & 3920.3 & 0.9 & 424.4 & 0.6 \\
\hline fuel & 4898.6 & 1.1 & 385.2 & 0.6 \\
\hline $\begin{array}{l}\text { spare parts. repair and construction } \\
\text { materials to repair }\end{array}$ & 21335.5 & 4.8 & 4266.8 & 6.2 \\
\hline Labour costs & 25234.4 & 5.7 & 3467.8 & 5.1 \\
\hline Other direct costs - total & 95016.8 & 21.4 & 15597.1 & 22.8 \\
\hline \multicolumn{5}{|l|}{ including } \\
\hline deductions on the social purposes & 5533.7 & 1.2 & 803.1 & 1.2 \\
\hline \multicolumn{5}{|l|}{ rent payments for } \\
\hline land shares (stocks) & 43952.0 & 9.9 & 7308.6 & 10.7 \\
\hline property shares & 429.5 & 0.1 & 63.6 & 0.1 \\
\hline depreciation of fixed assets & 25752.9 & 5.8 & 5566.8 & 8.1 \\
\hline Indirect costs - total & 74745.0 & 16.9 & 7807.7 & 11.4 \\
\hline \multicolumn{5}{|l|}{ including } \\
\hline $\begin{array}{l}\text { payment of services and job of other } \\
\text { organizations }\end{array}$ & 34233.5 & 7.7 & 4082.0 & 6.0 \\
\hline
\end{tabular}

${ }^{1}$ Data exclude the temporarily occupied territory of the Autonomous Republic of Crimea, the city of Sevastopol and a part of temporarily occupied territories in the Donetsk and Luhansk regions

2 Information is compiled by enterprises with the main economic activity "Growing of nonperennial crops", "Growing of perennial crops", "Plant propagation", "Animal production", "Mixed farming", "Support activities to agriculture and post-harvest crop activities" and "Processing and preserving of poultry meat" (codes 01.1-01.6 and 10.12 by NACE Rev. 2 2006). 
Costs for the purchase of fuel and lubricants in agricultural production are increasing every year and this leads to an increase in the cost of manufactured agricultural products.

Having analysed the above estimates of existing biomass and waste potential, the increase in biofuel production from agricultural waste will solve the problem of purchasing expensive fossil fuels by replacing them with biofuels. This will increase the competitiveness of domestic agricultural products by reducing the cost of production of agricultural products. Such waste-free technologies contribute to the sustainable development of society and provide energy autonomy for the agricultural sector.

Due to the difficult economic situation of Ukraine, caused by both internal and external problems, it is difficult to realise the very fast pace of bioenergy development. There remain many unresolved and complex problems in Ukrainian bioenergy. There is practically no clear strategy for the development of bioenergy at the state level, there is a strong opposition in the country from the leading energy companies and their lobby for the use of biological fuels, especially bioethanol and biogas, which are competitive for them. The volume of public and private investment in bioenergy, especially in the scientific and technical sphere, is still insufficient. The economic problems of bioenergy, especially incentive measures for the construction and further development of bioenergy facilities, remain virtually unsolved.

\section{Conclusions and Proposals}

In order to implement autonomous energy management of the agrarian sector and reduce the energy dependence of other sectors of the Ukrainian economy, it is necessary to take a number of measures and introduce a state policy on:

- harmonisation of legislative and regulatory acts of Ukraine with EU legislation on the promotion of the use of energy produced from renewable sources;

- promoting the development of economic activities aimed at reducing methane emissions from animal husbandry by installing biogas reactors, as well as from other primary products of the agroindustrial complex;

- expansion of sustainable biomass production for energy supply, which will increase the volume of biomass from agriculture and forestry (timber, agricultural waste and agricultural products, energy crops) for heat and electricity production and replacement of fossil fuels; 
- development and implementation of biomass conversion technologies by increasing the rate of development of the latest biomass conversion technologies and developing the market for such technologies for biofuels production and so on.

\section{REFERENCES}

1. Eurostat. Available at: https://ec.europa.eu/eurostat.

2. Official site of the State Statistics Service of Ukraine. Statistical information. Available at: http://www.ukrstat.gov.ua/.

3. The Food and Agriculture Organization (FAO). Available at: http://www.fao.org/faostat/ru/\# compare.

4. Andreichenko, A. V. (2017). Waste typology in agriculture: domestic and European experience. Economic Space, 124: 67-76.

5. Zamula, I. V., Bondarchuk V. V. (2013). Agricultural Waste Accounting: An Ecological Vector. Problems of Theory and Methodology of Accounting, Control and Analysis, 3 (27): 85-96.

6. Zarichanska, Ye. V. (2008). Clarification of the main classification characteristics of waste in the economic system. Proceedings of the IV Scientific-Practical Conference: 567-571. Available at: http://ea.donntu.edu.ua:8080/jspui/handle/ $123456789 / 9566$.

7. DG Agriculture and Rural Development / DG Energy - National Renewable Energy Action plans (NREAPs). Available at: https://ec.europa.eu/energy/topics/renewable-energy/national-renewable-energy-action-plans-2020_en?redir $=1$.

8. Kaletnik, G. M. (2018). Diversification of production of biofuel - as the basis of maintenance of food, power, economic and environmental safety of Ukraine. Bulletin of Agricultural Science, №11(788): 169-176. Available at: https:/doi. org/10.31073/agrovisnyk201811-21.

9. Roik, M. V, Ganzhenko, O. M., Tymoshchuk, V. L. (2014). The concept of biogas production from bioenergy plants in Ukraine. Bioenergy, 2. Available at: file:///C:/ Users/user/Downloads/Bioen_2014_2_2\%20(1).pdf.

10. Marchenko, V. M., Kit, A. V. (2018). Analysis of production potential of bioethanol from sugar beet in Ukraine. Agrosvit. Available at: http://www.agrosvit.info/ pdf/22_2018/5.pdf.

11. Kulakovska, T. A., Shekera, S. S. (2012). Analysis of the Ukrainian market of biological fuel from wastes of agricultural and industrial enterprises. Cereal products and compound forage,

12. State Classifier of Ukraine. Waste Classifier DK 005-96. Available at: http://plast. vn.ua/DK005-96.html.

13. Government of Ukraine (2004). The Law of Ukraine «Про державну підтримку сільського господарства України». (On State Support for Agriculture of Ukraine.) Information of the Verkhovna Rada of Ukraine, 49: 527. Available at: https://zakon.rada.gov.ua/laws/show/1877-15. 
14. Government of Ukraine (1998). The Law of Ukraine «(On Wastes) Про відходи». Information of the Verkhovna Rada of Ukraine, 36-37: 242. Available at: https:// zakon.rada.gov.ua/laws/show/ru/187/98-\%D0\%B2\%D1\%80.

15. Європейський каталог відходів. Available at: https://www.sustainabilityexchange.ac.uk/the_european_waste_catalogue_ewc.

16. Government of Ukraine (2000). The Law of Ukraine «Про альтернативні види палива» (On alternative fuels). Information of the Verkhovna Rada of Ukraine, 12: 94. Available at: https://zakon.rada.gov.ua/laws/show/1391-14.

17. Government of Ukraine (2017). Національна стратегія відходами в Україні до 2030 року. (Ukrainian National Waste Management Strategy until 2030) Available at: https://zakon.rada.gov.ua/laws/show/820-2017-\%D1\%80.

18. Kaletnik, G. M., Goncharuk, T. V. (2013). Innovative support for the development of the biofuel industry: world and national experience. Business Inform, 9: 155-160. Available at: http://www.irbis-nbuv.gov.ua/cgi-bin/irbis_nbuv/cgiirbis 64.exe?I21DBN $=$ LINK\&P21DBN $=$ UJRN \&Z21ID $=\& S 21 R E F=10 \& S 21 \mathrm{CNR}=20 \overline{8}$ $\mathrm{S} 21 \mathrm{STN}=1 \& \mathrm{~S} 21 \mathrm{FMT}=\mathrm{ASP} \_$meta $\& C 21 \mathrm{COM}=\mathrm{S} \& 2 \_\mathrm{S} 21 \mathrm{P} 03=\mathrm{FILA}=\& 2 \_\mathrm{S} 21 \mathrm{STR}=$ binf_2013_9_26.

19. Honcharuk, I. V., Tomashuk, I. V. (2017). Influence of ecological and economic factor on peculiarities of organizational and economic mechanism of utilization of the resource potential of rural territories. Economy. Finances. Management: topical issues of science and practice, 4: 52-62. Available at: http://repository.vsau.org/ getfile.php/15770.pdf.

21. Angheluta, S. P., Burlacu, S., Diaconu, A., \& Curea, C. S. (2019). The Energy from Renewable Sources in the European Union: Achieving the Goals. European Journal of Sustainable Development, 8(5): 57-65. https://doi.org/10.14207/ejsd.2019.v8n5p57.

22. Lybæk, R., Christensen, T. B., \& Kjær, T. (2013). Enhancing the Transition Capability of Danish Biomass Technology By Applying a Futures Study Backcasting Methodology on the Biogas Sector. European Journal of Sustainable Development, 2(4): 37-50. https://doi.org/10.14207/ejsd.2013.v2n4p37.

23. Fei Li, Shengkui Cheng, Huilu Yu, Dewei Yang (2016). Waste from livestock and poultry breeding and its potential assessment of biogas energy in rural China. Journal of Cleaner Production, 126: 451-460. https://doi.org/10.1016/j. jclepro.2016.02.104.

24. Trypolska, H. S., Diachuk, O. A., Podolets, R. Z., Chepeliev, M. H. (2016). Biogas projects in Ukraine: prospects, consequences and regulatory policy. Economics and forecasting, 2: 111-134. https://doi.org/10.15407/eip2018.02.111. 